\title{
Serum IgG subclass antibodies to a variety of food antigens in patients with coeliac disease
}

\author{
M Hvatum, H Scott, P Brandtzaeg
}

\begin{abstract}
Levels of serum IgA, IgG, and IgG subclass antibodies to a variety of dietary antigens were determined by enzyme linked immunosorbent assays in 14 adults with untreated coeliac disease and in 10 disease controls selected because of raised total IgG activities. The untreated coeliacs showed somewhat higher total IgG activity $(p \sim 0.05)$ and significantly raised IgA and IgG1 + IgG3 activities to gliadin but reduced IgG4 activity $(p<0.02)$ compared with the controls. High IgA and IgG1+IgG3 activities were positively correlated $(r=0.67$, $\mathbf{p}<\mathbf{0 . 0 1}$ ), and so were IgG and IgG4 activities $(\mathrm{r}=0.64, \mathrm{p}<0.02)$. Conversely, a high IgG2 response to gliadin appeared related to a low IgA response $(r=0.55, p<0.05)$. The IgG2 response was most prominent to oat flour antigens, followed by IgG1; and the main response to soy antigens resided in IgG1, followed by IgG2 in both disease groups. There was no difference in antibody activities to oat and soy between the two groups, and raised activity to bovine serum albumin was seldom encountered. The IgA activity to $\alpha$-lactalbumin and ovalbumin tended to be increased in the coeliacs compared with the controls. The IgG4 subclass dominated the IgG response to $\beta$-lactoglobulin and ovalbumin and was often raised to $\alpha$-lactalbumin, especially in the disease controls. The IgG subclass pattern to casein parallelled that to gliadin with dominance of the IgG1- and IgG3-subclass activities, especially in the coeliacs. The phlogistic potential of a response in these two subclasses might be relevant to the pathogenesis of coeliac disease and could contribute to a raised IgA gliadin response by increasing mucosal permeability. IgG4 activity seemed to be highest against antigens usually involved in IgE mediated food allergy.
\end{abstract}

Small intestinal villous atrophy in coeliac disease is most likely induced by an abnormal immune response to gluten. IgG antibodies may be of pathogenic importance in addition to activated $T$ lymphocytes and various cytokines. ' IgG is extravascularly distributed, its interstitial concentration being at least half of that in serum. ${ }^{2}$ Both locally produced and circulating IgG with complement activating properties and specificity for gluten $^{3}$ or other luminal antigens ${ }^{+}$are thus available for mucosal immune reactions.

In adult coeliac disease, the IgG fraction of mucosal immunoglobulin producing cells was found to be most markedly increased in relative terms. $^{5}$ Moreover, in children with coeliac disease, an inverse linear relationship was noted between time to clinical relapse after gluten challenge and the mucosai IgG cell number. ${ }^{6} \mathrm{~A}$ raised serum IgG activity to gluten and other dietary antigens was found in most patients with untreated coeliac disease. ${ }^{+7-13}$ Fairly high levels of such antibodies were also present in patients with other intestinal disorders, however, and in some healthy individuals. ${ }^{1213}$

Serum IgG consists of $60-70 \%$ IgG, $12-18 \%$ IgG2, 5-8\% IgG3 and 0.7-5\% IgG4. ${ }^{1+15}$ The mechanisms regulating IgG subclass responses are obscure, but the nature of the antigen definitely plays an important role. The phlogistic IgG1 and IgG3 antibodies are elicited mainly by protein antigens - for example, virus infections, as opposed to IgG2 which is stimulated preferentially by bacterial carbohydrates. ${ }^{1+}$ Genetic factors may additionally influence the IgG subclass response. ${ }^{1+16}$

Because the subclass profile determines the complement activating properties of IgG antibodies, it may be important for the local effect of an immune response to food antigens. We therefore studied the relative subclass distribution of serum IgG antibodies to proteins from flour, egg, and cow's milk in patients with untreated coeliac disease; patients with various other intestinal disorders and high serum IgG activity were used as disease controls.

\section{Methods}

\section{PATIENTS}

Serum samples from 14 adults with untreated coeliac disease (seven men, seven women; median age 49 years, range 17-68) and 10 adult disease controls (five men, five women; median age 46 years, range 21-72) were examined. The diagnosis of coeliac disease was based on the demonstration of small intestinal villous atrophy that improved on a gluten free diet. The 10 disease control patients were selected on the basis of routine measurements of serum $\operatorname{IgA}$ and $\operatorname{IgG}$ antibodies to various dietary antigens, raised IgG activity being a prerequisite to make IgG subclass antibody determinations possible. Intestinal biopsy showed normal mucosal morphology in the nine controls examined histologically. The clinical diagnoses of the control patients are listed in Table I. Blood samples were obtained from all patients on admission to the hospital before any treatment was initiated, and sera were stored at $-20^{\circ} \mathrm{C}$.

\section{ANTIGENS}

The following antigens were used: Gliadin (Carl Roth, Karlsruhe, Germany), ovalbumin grade III, bovine $\alpha$-lactalbumin, $\beta$-lactoglobulin and casein (Sigma Chemical Company, St Louis, \\ Immunohistochemistry \\ (LIIPAT) \\ Hospital, Rikshospitalet, \\ Oslo, Norway \\ H Scott
}


TABLE I Clinical diagnoses of control patients

\begin{tabular}{ll}
\hline Diagnoses & $\begin{array}{l}\text { Patients } \\
(n)\end{array}$ \\
\hline $\begin{array}{l}\text { Possible gluten intolerance without intestinal villous } \\
\text { atrophy }\end{array}$ & 1 \\
Irradiation injury & 1 \\
Cirrhosis of the liver & 1 \\
Unclassified connective tissue disorder & 1 \\
Mother of a child with paroxysmal disorder and & 1 \\
increased gluten antibody levels & 1 \\
T-cell deficiency & 4 \\
\hline
\end{tabular}

Missouri, USA), bovine serum albumin (BSA) (Behringwerke AG, Marburg, Germany) and oat and soy flour from a local mill (Møllesentralen, Oslo, Norway). Extracts of oat and flour was made in $0.01 \mathrm{M}$ ammonium acetate, $\mathrm{pH} 7 \cdot 0$, by repeated freezing and thawing, alternating with vibration. After centrifugation the extracts were passed through a $0.8 \mu \mathrm{m}$ Millipore filter. The other antigens were also dissolved in $0.01 \mathrm{M}$ ammonium acetate, except gliadin, which was solubilised in $70 \%$ ethanol.

\section{ANTIBODIES}

Rabbit antisera to human IgG and IgA (code nos A423 and A262) and alkaline phosphatase conjugated rabbit antimouse Ig (code D314, raised against IgG) were obtained from Dakopatts (Glostrup, Denmark). Alkaline phosphatase conjugated swine antirabbit IgG was from Orion Diagnostica (Espoo, Finland). Monoclonal antibodies were used for IgG subclass determinations. A mix of HP6070 and HP6012 (clones 2C7 and NL16, respectively) both at a final dilution of 1:1500, was used for IgG1, while HP6014, HP6010 and HP6011 (clones AC3 AA11, ZG4 and RJ4) were used for IgG2, IgG3 and IgG4, respectively, at dilutions 1:2000, 1:4000 and $1: 4000$. HP6070 was a kind gift from Dr O Mäkelä, Helsinki, Finland. The other monoclonal antibodies were purchased from Oxoid (Hampshire, UK).

ENZYME LINKED IMMUNOSORBENT ASSAY (ELISA) The serum samples were tested for specific $\operatorname{IgA}$, IgG, and IgG subclass activities by ELISA in Costar microtitre plates no 3590 (Cambridge, MA, USA), coated for 20 hours at room temperature with gliadin $(10 \mu \mathrm{g} / \mathrm{ml})$, extracts of oat and soy flour (70 and $100 \mu \mathrm{g} / \mathrm{ml}$ ), casein, and

TABLE II Median and observed range (ELISA units) for serum IgG and IgA activities to different dietary antigens in untreated coeliac disease and in controls with various other disorders and raised IgG antibody levels

\begin{tabular}{|c|c|c|c|c|}
\hline \multirow[b]{2}{*}{ Antigen } & \multicolumn{2}{|l|}{ Coeliac patients ${ }^{\star}$} & \multicolumn{2}{|l|}{ Disease controls ${ }^{\star}$} \\
\hline & $\operatorname{Ig} G$ & $\operatorname{Ig} A$ & $I g G$ & $\operatorname{Ig} A$ \\
\hline $\begin{array}{l}\text { Gliadin } \\
\text { Oat } \\
\text { Soy } \\
\text { p-lactoglobulin } \\
\alpha \text {-lactalbumin } \\
\text { Casein } \\
\text { Ovalbumin }\end{array}$ & $\begin{array}{c}365(102-1143) \dagger \\
89(0-277) \\
15(0-86) \\
8(0-265) \\
90(0-355) \\
62(8-301) \\
132(10-976)\end{array}$ & $\begin{array}{c}342(62-1664) \dagger \\
55(0-539) \dagger \\
7(0-154) \\
4(0-82) \\
170(0-1142) \dagger \\
60(0-355) \\
52(11-301) \dagger\end{array}$ & $\begin{array}{c}143(25-1000) \\
44(34-277) \\
13(0-120) \\
8(0-52) \\
97(44-320) \\
64(0-125) \\
87(0-1000)\end{array}$ & $\begin{array}{l}80(57-785) \\
35(3-130) \\
4(0-8) \\
8(0-34) \\
79(32-206) \\
46(0-168) \\
21(0-130)\end{array}$ \\
\hline
\end{tabular}

* Coeliacs were significantly different from a group of 28 patients with rheumatoid arthritis in specific IgA and IgG to all antigens $(p<0.025$ to $p<0.0005)$. Control disease patients differed from that group ig and IgGe (to all antigens $(\mathrm{p}<0.05$ to $\mathrm{p}<0.0005$ ), but only in IgA activity to gliadin, casein, and ovalbumin $(p<0.025$ to $p<0.005) ;+$ significant differences compared with the control disease group $(\mathrm{p} \leq \mathbf{0 . 0 5})$. $\alpha$-lactalbumin $\quad(2 \mu \mathrm{g} / \mathrm{ml}), \quad \beta$-lactoglobulin $(50 \mu \mathrm{g} / \mathrm{ml})$, BSA and ovalbumin $(100 \mu \mathrm{g} / \mathrm{ml})$ as detailed elsewhere. ${ }^{17}$ The plates were next washed with deionised water, and blocked with $0.5 \%$ $(\mathrm{w} / \mathrm{v})$ BSA in $0.01 \mathrm{M}$ potassium phosphate $(\mathrm{pH} 7)$ between three hours and 20 hours at convenience. An exception was plates coated with $\alpha$-lactalbumin or BSA, which were used immediately without blocking because $0.5 \%$ BSA apparently interferred with the former antigen and produced an excessive and unstable coat of the latter antigen. Also gelatin was found to be unsatisfactory as a blocking agent with the applied antigens. ${ }^{17}$

Before use the plates were washed with $0 \cdot 15 \mathrm{M}$ $\mathrm{NaCl}$ containing $0.05 \%$ Tween 20 (washing solution) and incubated with serum samples in appropriate dilutions for 1.5 hours. After a new wash, the plates were incubated with the primary antibody for 1.5 hours, washed and incubated with the alkaline phosphatase conjugated secondary antibody for 1.5 hours. After a final wash, phosphatase substrate was added and optical density was read at $405 \mathrm{~nm}$. The test sera and antibody reagents were diluted in $0.01 \mathrm{M}$ potassium phosphate ( $\mathrm{pH} 7$ ) with $0.5 \mathrm{M} \mathrm{NaCl}, 0.05 \%$ Tween 20 and $0.5 \%$ BSA, except for measurements of antibody activities to $\alpha$-lactalbumin and BSA, for which $0.3 \%$ gelatin satisfactorily could replace BSA in the diluent. The incubations took place at room temperature in an insulated box to ensure even temperature and ended with vibration for at least one hour. All tests were performed in triplicate.

\section{EXPRESSION OF ELISA RESULTS}

For measurements of IgA and IgG antibodies, the serum samples were diluted 1:200 and the test results were read from a reference curve obtained by serial dilutions of a standard serum reacted against gliadin in each plate. ${ }^{17}$ This serum was pooled from patients with untreated coeliac disease and assigned 1000 arbitrary units of $\mathrm{IgA}$ and IgG activity per millilitre in relation to which all antibody results were expressed. It was thereby avoided to make a new standard for each antigen, and it was deemed to be advantageous for standardisation to have a common reference. This was acceptable because of the semiquantitative nature of the assay. ${ }^{17}$

The measurement of IgG subclass activities was based on two serum dilutions for IgG2 and IgG3, and three for IgGl and IgG4. The actual dilutions were adjusted according to the patient's total IgG activity against the same antigen, the starting dilution varying from $1: 10$ to $1: 100$. A reference curve was constructed on each plate (and for every antigen) by letting a mix of all subclass specific antibodies (IgG1-4) react in ELISA with five dilutions of the patient's own serum and three wells without serum. The starting dilution was two-fold higher than that used for the individual subclasses. The Cricket/ Graph-program for Macintosh PC was used to draw a semi logarithmic dose response curve for each subclass as well as for the reference, against which the percentage subclass activities were read manually. The result was usually based on the serum dilution falling nearest to the middle 

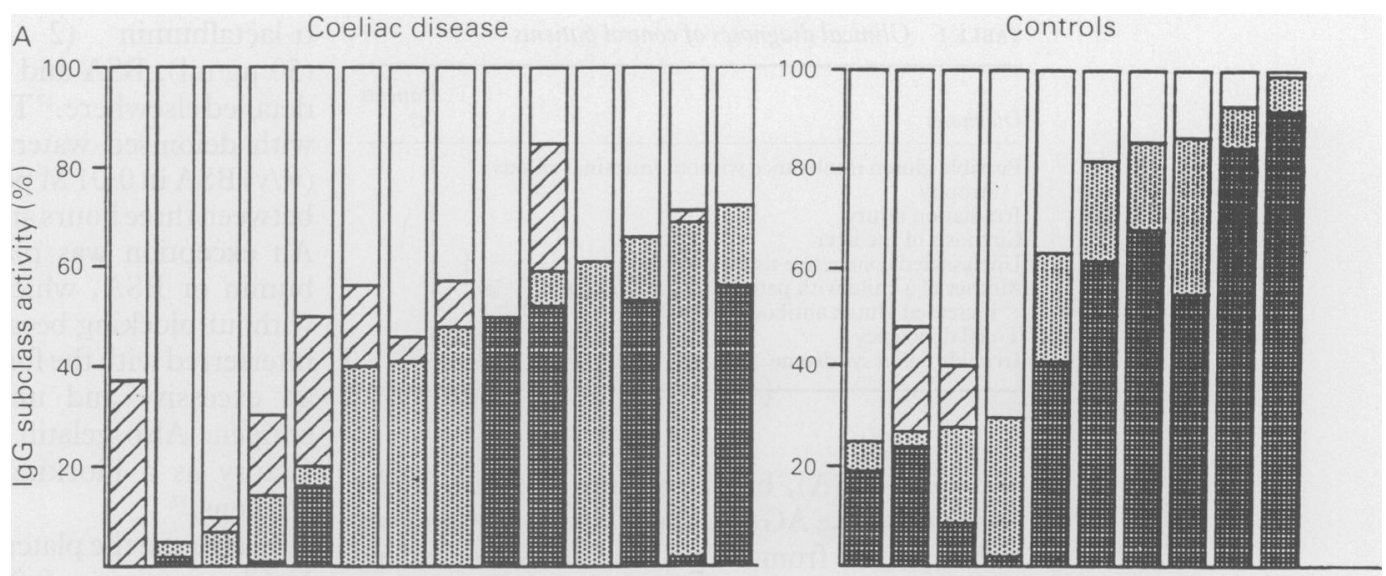

B
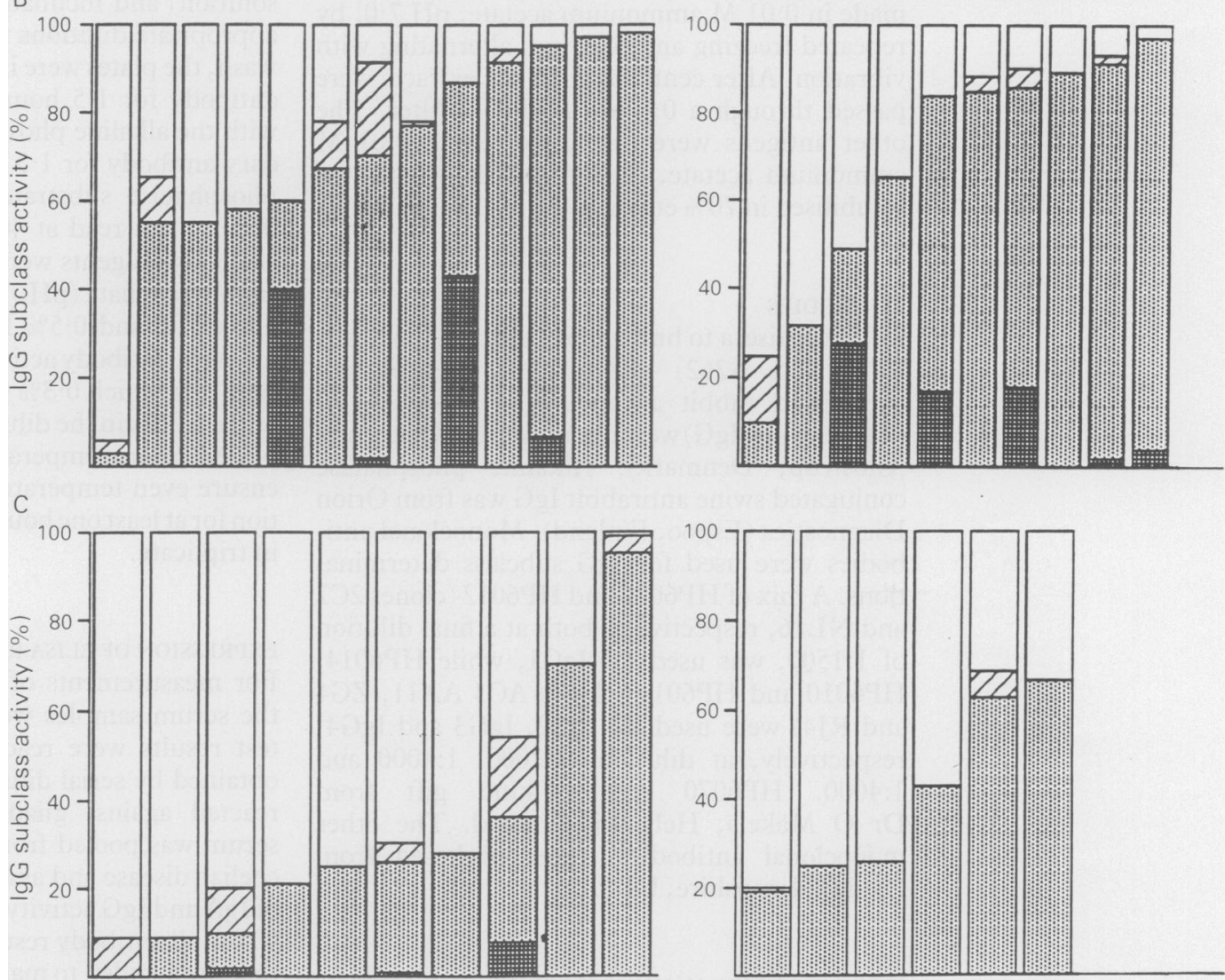

Figure 1: ELISA determinations of IgG subclass activities to gliadin $(A)$, oat flour $(B)$, and soy flour $(C)$ in coeliac disease and controls as indicated. $(\square=I g G 1 ;$ 橉 $=I g G 2 ; \forall=I g G 3 ; \mathbf{\square}=I g G 4)$. Each staked column represents the reaction of one serum sample with one antigen. For each antigen the serum samples in both disease groups are sorted after increasing $\operatorname{Ig}(\mathrm{G} 2+\operatorname{IgG} 4$ activities; thus the order of the samples varies.

of the reference curve, but when the dose response curves deviated the middle of two sample dilutions was used. ${ }^{17}$ To compensate for the many variables in the measurements, the percentage activities determined for the four IgG subclasses were proportionately adjusted to produce a sum of $100 \%$ for each sample.

SPECIFICITY

To examine if IgG antibodies to gliadin cross reacted with antigens from oat or soy flour, serial dilutions of the respective extracts were added to test sera (four from the group with coeliac disease and four from the control group) and the IgG activity to gliadin was measured by ELISA.
STATISTICAL ANALYSES

Comparisons between groups of IgA and IgG to food antigens were based on Wilcoxon's test for unpaired samples (two-tailed). Comparisons of antibody results within groups were based on regression analysis.

\section{Results}

ANTIBODIES TO GLIADIN, OAT AND SOY

\section{Gliadin}

Patients with untreated coeliac disease had significantly higher IgA $(p<0.02)$ and slightly higher $\operatorname{IgG}(p \sim 0.05)$ activity in serum than the disease 


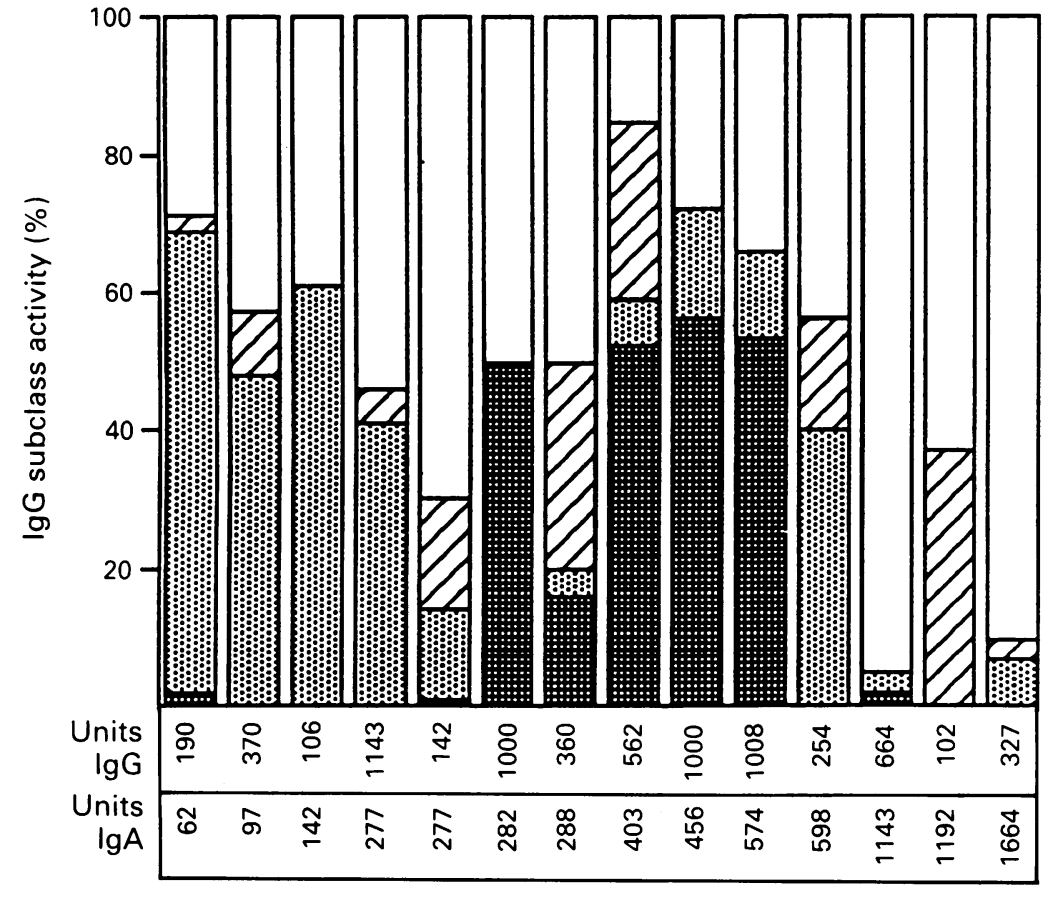

Figure 2: ELISA determinations of IgG subclass activities (\%) related to total IgA and IgG activity units (bottom lines) against gliadin in sera from patients with untreated coeliac disease. $(\square=I g G 1 ;$ 国=IgG2; $=I g G 3 ; \square=I g G 4)$.

control group (Table II). The IgG-subclass pattern varied considerably in both groups. On the whole, however, the untreated coeliacs had relatively lower IgG4 activity $(\mathrm{p}<0.02)$ and higher IgG1 + IgG3 activity $(\mathrm{p}<0.02)$ to gliadin than the disease controls (Fig 1A). Nevertheless, the proportion of IgG4 activity to gliadin was rather high in five of the 14 patients with coeliac disease compared with the normal percentage of total IgG4 in serum. Most of the patients with little or no IgG4 activity seemed to compensate with IgG2 activity. High relative IgG1+IgG3 antibody levels to gliadin showed positive correlation with a high IgA gliadin response $(\mathrm{r}=0.67, \mathrm{p}<0.01)$, while a high IgG2 response was related to a low $\operatorname{IgA}$ response $(r=-0.55$, $\mathrm{p}<0.05$ ) (Fig 2). Relatively high IgG4 antibody levels were associated with a high IgG response to gliadin $(r=0.64, p<0.02)$. There were no such significant correlations in the control group.

\section{Oat}

Total IgG activity and the various IgG subclass activities to oat antigen were similar in untreated coeliacs and disease controls, while the former patients tended to show higher IgA activity $(\mathrm{p} \sim 0.05)$ (Table II). The dominating IgG subclass activity to oat in both subject categories resided in IgG2, which contributed to more than $50 \%$ of the total IgG activity in 10 of 13 coeliacs and in seven of 10 disease controls (Fig 1B). The IgG subclass pattern was not dependent on the total IgA or IgG activity.

Soy

Most IgG activity to soy antigens resided in IgG 1 and IgG2 (Fig 1C). The former subclass activity dominated, except in two patients with coeliac disease and two disease controls (65\%-95\% IgG2 activity). There was no apparent difference in the total IgA or IgG activity to soy or in the IgG subclass activity profile when the coeliacs were compared with the controls (Table II).

\section{ANTIBODIES TO MILK PROTEINS}

\section{$\beta$-lactoglobulin}

No difference in $\operatorname{IgA}$, IgG, or IgG subclass activities to $\beta$-lactoglobulin appeared between the two categories of patients. Both groups showed a significantly higher proportion of IgG4 activity $(\mathrm{p}<0.01)$, however, and a significantly lower proportion of IgG2 activity $(\mathrm{p}<0.01)$ to $\beta$ lactoglobulin than to oat antigens. More than $50 \%$ of the IgG activity to $\beta$-lactoglobulin was expressed by IgG4 in all disease controls and in eight of 10 patients with untreated coeliac disease (Fig 3A). Four coeliacs and one disease control did not have measurable IgG activity to $\beta$-lactoglobulin.

\section{$\alpha$-lactalbumin}

There was no significant difference in IgG or IgG subclass activities when untreated coeliacs were compared with disease controls. The former group had significantly higher IgA activity to $\alpha$-lactalbumin $(p<0.05)$, however, (Table II). As for IgG antibodies to $\beta$-lactoglobulin, the subclass profile was dominated by IgG4 activity, especially in the disease control group where it represented more than $50 \%$ in six of 10 patients. IgG2 + IgG4 antibodies contributed to more than $50 \%$ of the total IgG activity to $\alpha$-lactalbumin in eight of 10 disease controls and in seven of 13 of the untreated coeliacs (Fig 3B).

\section{Casein}

As for gliadin, the IgG subclass activity to casein varied considerably in both groups. There tended to be a higher proportion of IgG1 + IgG3 antibodies to casein than to the other milk proteins in both categories of patients, and especially in the coeliacs (Fig 3C). No significant difference in IgG and IgA activity to casein appeared between coeliacs and disease controls.

\section{Bovine serum albumin}

Only few patients of both categories had raised IgG and IgA activity to BSA. Most of the IgG subclass activity resided in IgG1 and IgG4 (data not shown).

\section{ANTIBODIES TO OVALBUMIN}

Patients with untreated coeliac disease tended to have increased IgA activity to ovalbumin compared with the disease controls $(p \sim 0.05)$, but there was no significant difference in the total IgG activity (Table II) or its subclass profile between the two subject categories. As for IgG antibodies to $\beta$-lactoglobulin and $\alpha$-lactalbumin, a considerable proportion of the activity to ovalbumin resided in IgG4, both in coeliacs and disease controls (data not shown). More than $60 \%$ of the IgG activity to ovalbumin was 

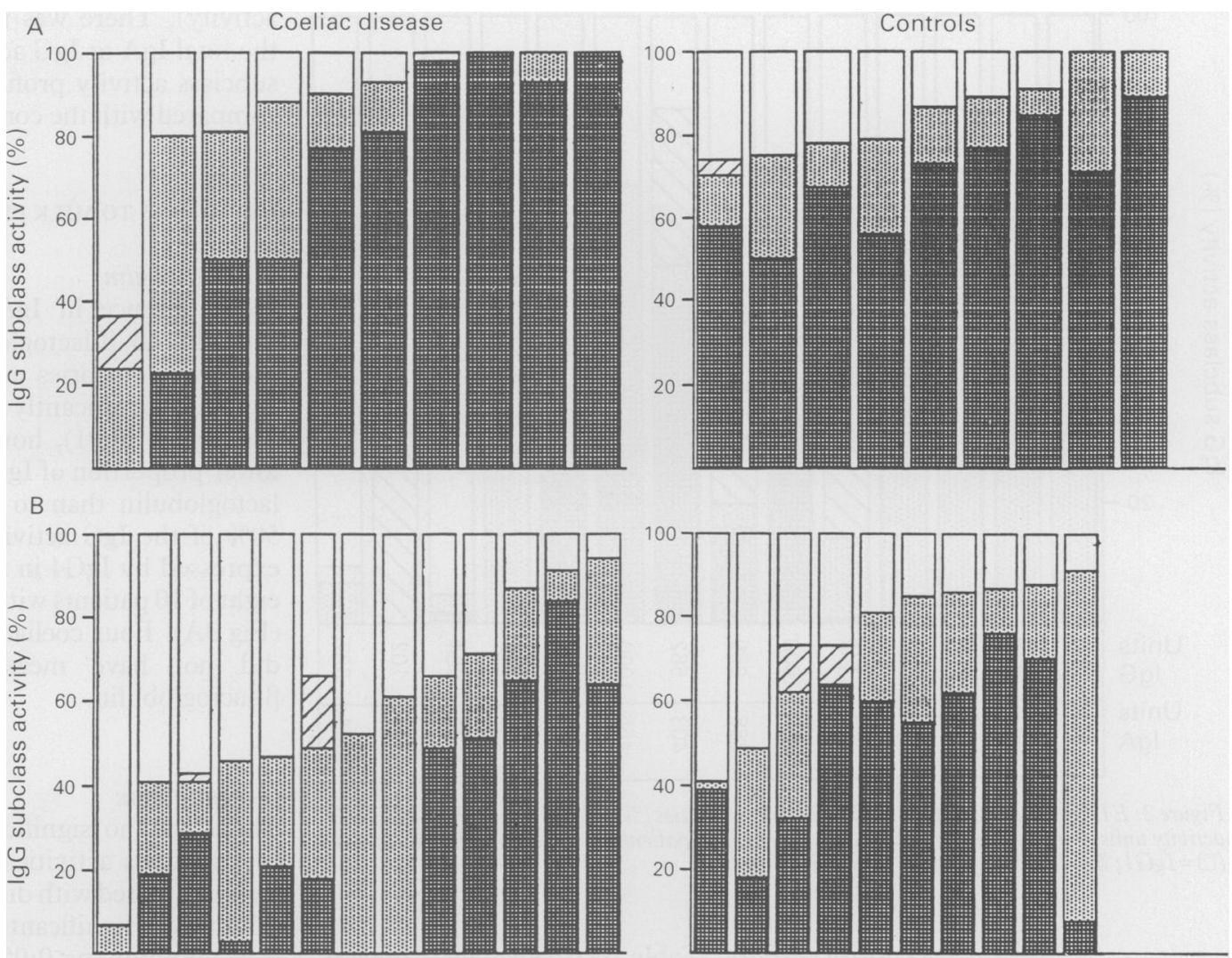

C
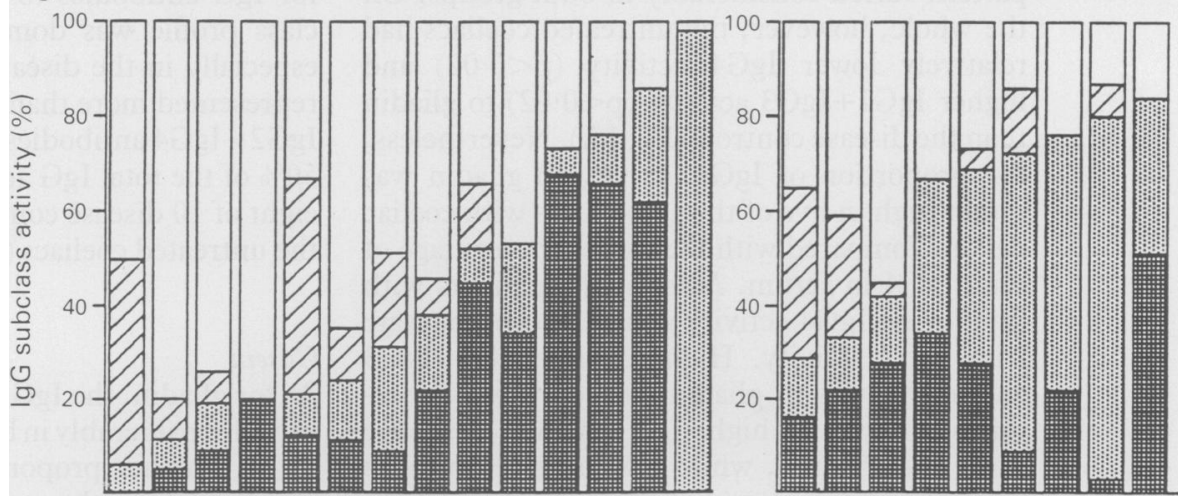

Figure 3: ELISA determinations of IgG subclass activities to $\beta$-lactoglobulin $(A),(\ell$-lactulbumin $(B)$, and casein $(C)$ in coeliac

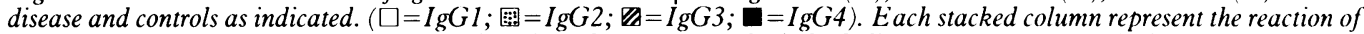
one serum sample with one antigen. For each antigen the serum samples in both disease groups are sorted after increasing $I g G 2+I g G 4$ activities; thus the order of the samples varies.

expressed by IgG4 in all disease controls, and more than $50 \%$ was expressed by $\operatorname{IgG} 2+\operatorname{IgG} 4$ in 11 of 14 coeliacs.

POSSIBLE CROSSREACTIONS BETWEEN GLIADIN AND OAT ANTIGENS

Additions of up to $200 \mu \mathrm{g}$ proteins (two fold dilutions) from oat flour extract to eight test sera did not inhibit the IgG activity to gliadin (data not shown).

\section{Discussion}

The IgG subclass activities to gliadin and casein showed large individual variations but occurred predominantly in IgGl and/or IgG4. Noteably, the latter subclass activity to gliadin was significantly lower in untreated coeliacs than in disease controls who had been selected because of high
IgG activity to various dietary antigens. Husby et $a l^{18}$ detected IgG1 and IgG3 antibodies to gluten in most untreated children with coeliac disease, whereas none of 22 normal controls were reported to have appreciable IgGl activity and only one had IgG3 activity. A predominant increase in IgGl activity to gluten in untreated coeliacs has been reported also by others. ${ }^{19}: 1: 2$ Conversely, Barnes et al $l^{\prime \prime}$ found that the IgG antibodies to milk and gluten were often quite restricted to IgG4, in adult coeliacs and healthy subjects, which was never the case for gliadin antibodies in our coeliac patients.

The results of IgG subclass activity measurements depend considerably on the monoclonal antibodies and the assay used ${ }^{17}$ but also on the composition of the test groups. Such variables may explain some of the reported discrepancies. In both our test groups, however, it seems that the serum IgG subclass activity to gliadin, casein, 
$\beta$-lactoglobulin and ovalbumin resides relatively more in IgG4 than expected from the protein level of this subclass in serum $(0 \cdot 7-5 \%$ of total IgG) and the distribution of IgG producing mucosal plasma cells. ${ }^{23}$ Similar findings have been reported by others, ${ }^{18-20}$ and the IgG4 antibody activity has appeared unrelated to the total IgG4 level..$^{2+}$ Perhaps most of the IgG antibodies to dietary antigens are produced in mesenteric lymph nodes.

It is well established that the IgG subclass response varies with the antigen. ${ }^{15}$ Production of IgG4 antibodies may be part of a normal immune response to several dietary proteins ${ }^{20}$ as also suggested by a relatively high proportion of IgG4 producing cells in Peyer's patches. ${ }^{25}$ IgG4 is, moreover, relatively prominent in serum antibody responses to antigens such as dust, mite, pollen, bee venom, clotting factor VIII, schistosomiasis filariasis, thyroglobulin, and DNA. ${ }^{26}$ In previous studies the antigen exposition has varied from ingestion, inhalation, injection, infusion and infection to autoimmunisation. IgG4 has been reported to increase after prolonged antigen stimulation, ${ }^{2728}$ although these observations were made in individuals undergoing hyposensitisation by injections rather than mucosal stimulation. A B-cell isotype switch pattern, first from $\operatorname{IgG} 1$ to $\operatorname{IgA} 1$ and subsequently from $\operatorname{IgA} 1$ to IgG4, has been suggested by Hammarström et $a l^{29}$; but there may also be a direct switch from IgM to IgA 1 and IgG4.$^{29}$ In addition, the relative IgG subclass activities obtained by hyposensitisation seem to be influenced by the use of adjuvant, ${ }^{30}$ indicating that the profile to an antigen may depend on other stimulatory variables.

Stimulation with common food antigens has necessarily lasted for a long time in adults. Despite this fact, oat and soy were seldom or never found to elicit raised IgG4 antibody levels. Conversely, predominant IgG2 activity was detected to these antigens, perhaps reflecting a relatively high carbohydrate content. Unlike protein antigens, polysaccharides do not induce a switch from IgGl to IgG4. ${ }^{31}$ It appeared as if a small or no production of IgG4 antibodies was compensated by a relatively high IgG2 activity. IgG4 antibodies have no, ${ }^{1+}$ and IgG2 usually little, complement activating capacity ${ }^{32}$; and IgG2 shows poor Fc $\gamma$ receptor binding. ${ }^{33}$ Under conditions with appropriate epitope density and concentrations of antigen, antibody and complement, the relative complement binding activity of IgG1, IgG2 and IgG3 may change, however. ${ }^{3+35}$ It is hence uncertain to what degree IgG2 antibodies are of pathogenic significance in coeliac disease.

IgG4 antibodies show no significant binding to Fc $\gamma$ receptors on human monocytes and lymphocytes and are apparently always unable to activate the classical complement pathway. ${ }^{14}$ Conversely, $\mathrm{Fc}$ fragments of IgG4 apparently have the same $\mathrm{Cl}$-activating capability as $\mathrm{Fc} \gamma \mathrm{l}$ fragments. ${ }^{36}$ Van der Zee $e t a l^{37}$ found that addition of equal amounts of IgG4 to IgG1 resulted in $75 \%$ decrease of complement activation by phospholipase-A. Inhibition of complement activation was demonstrable even when the IgG4 activity represented only $20-25 \%$ of the total antigen binding capa- city. The role of IgG4 in allergic conditions, however, is still being debated. The existence of subtypes of IgG4 with different biological functions has been postulated. ${ }^{38}$ IgG4 may have a protective role against hypersensitivity by blocking antigen binding to IgE on basophils and mast cells. ${ }^{39}$ It has also been speculated that IgG4 (or a fraction of this subclass) present in small amounts on mast cells and basophils, may act as a sensitiser (SST IgG), whereas large amounts may act as blocking antibodies. ${ }^{38}$

Antigen stimulated histamine release has been observed in patients without measureable IgE activity to the antigen. ${ }^{38+0}$ The anaphylatoxins (complement fragments $\mathrm{C} 3 \mathrm{a}$ and $\mathrm{C5a}$ ) can induce mast cell degranulation, ${ }^{+1}$ and Lavö and coworkers $^{+2}$ have reported that challenge with gliadin induces activation of eosinophils and mast cells in the jejunum of patients with coeliac disease. The observed shift from IgG4 towards phlogistic IgGl antibodies to gluten in coeliac disease may thus be of pathogenic importance also for an immediate type reaction.

Spillover from the increased mucosal IgA production can, at least partially, explain the increased serum level of $\operatorname{IgA}$ in untreated coeliacs; there is thus a positive correlation between circulating IgA gliadin antibodies and the number of jejunal IgA immunocytes. ${ }^{+3} \mathrm{Con}-$ ceivably, an intestinal immune reaction involving phlogistic IgG antibodies may lead to enhanced intestinal permeability, increased antigen exposition, intensified production of blocking IgA antibodies, and raised IgA activity in serum. This may explain that the highest serum IgA activity to gliadin was found in patients with the most pronounced shift from IgG4 or IgG2 to the potentially phlogistic IgG1+IgG3 antibody activities. Complement activating IgG antibodies may therefore be of significance in the pathogenesis of coeliac disease, and activated complement has indeed been found beneath the jejunal epithelium in untreated coeliac patients. ${ }^{+4}$ The importance of the relatively high IgG2 activity to gliadin in most patients without comparable IgG4 activity, remains obscure but may reflect reduced down stream switching on the distal chromosomal segment where the $\mathrm{CH} \gamma 2$ and $\mathrm{CH} \gamma 4$ genes both are located.

We thank Kathrine Hagelsteen Kvien for skillful help. This study was supported by the Norwegian Research Council for Science and the Humanities, the Norwegian Cancer Society and Ander Jahre's Fund.

1 Brandtzaeg P, Bengtsson U, Halstensen TS, Hvatum M, Kett $\mathrm{K}$, Rognum TO, et al. Mucosal immunology and food antigens. Bibl Nutr Dieta 1991; 48: 30-54.

2 Poulsen L. Interstitial fluid concentration of albumin and immunoglobulin G in man. Scand 7 Clin Lab Invest 1974; 34: 119-22.

3 Gallagher RB, Cervi P, Kelly J, Dolan C, Weir DG, Feighery $C$. The subclass profile and complement activating potential of anti-a-gliadin antibodies in coeliac disease. $f$ Clin Lab Immunol 1989; 28: 115-21

4 Scott H, Fausa O, Ek J, Brandtzaeg P. Immune response patterns in coeliac disease. Serum antibodies to dietary antigens measured by an enzyme-linked immunosorbent assay (ELISA). Clin Exp Immunol 1984; 57: 25-32.

5 Baklien $\mathrm{K}$, Brandtzaeg P, Fausa $\mathrm{O}$. Immunoglobulins in jejunal mucosa and serum from patients with adult coeliac disease. Scand f Gastroenterol 1977; 12: 149-59.

6 Scott H, Ek J, Baklien K, Brandtzaeg P. Immunoglobulinproducing cells in jejunal mucosa of children with coeliac disease on a gluten-free diet and after gluten challenge. Scand 7 Gastroenterol 1980; 15: 81-8. 
7 Juto $P$, Fredrikzon B, Hernell $O$. Gliadin specific serum immunoglobulins $\mathrm{A}, \mathrm{E}, \mathrm{G}$ and $\mathrm{M}$ in childhood: Relation to small intestine mucosal morphology. $\mathcal{F}$ Pediatr Gastroenterol Nutr 1985; 4: 723-9.

8 Bürgin Wolff A, Berger R, Gaze H, Huber H, Lentze MJ, Nusslé $\mathrm{D}$. IgG, IgA and IgE gliadin antibody determinations as screening test for untreated coeliac disease in children, a multi centre study. Eur F Pediatr 1989; 148: 496-502.

9 Ståhlberg MR, Savilahti E, Viander M. Antibodies to gliadin by ELISA as a screening test for childhood celiac disease. f Pediatr Gastroenterol Nutr 1986; 5: 726-9

10 Stenhammar L, Kilander AF, Nilsson L-Á, Strömberg L, Tarkowski A. Serum gliadin antibodies for detection and control of childhood coeliac disease. Acta Pediatr Scand 1984; 73: 657-63.

11 Friiz SV, Gudmand Høyer E. Screening for coeliac disease in adults by simultaneous determination of Ig A and IgG gliadin antibodies. Scand $\mathcal{F}$ Gastroenterol 1986; 21 : 1058-62.

12 Scott H, Ek J, Havnen J, Michalsen H, Brunvand L, Howlid $\mathrm{H}$, et al. Serum antibodies to dietary antigens: a prospective study of the diagnostic usefulness in celiac disease of children. 7 Pediatr Gastroenterol Nutr 1990; 11 : 215-20.

13 Scott H, Fausa O, Ek J, Valnes K, Blystad L, Brandtzaeg P. Measurements of serum IgA and IgG to dietary antigens: a prospective study of their diagnostic usefulness in adult coeliac disease. Scand F Gastroenterol 1990; 25: 287-92.

14 Papeda C, Check IJ. Human immunoglobulin G and immunoglobulin G subclasses: biochemical, genetic and clinical globulin G subclasses: biochemical, genetic
aspects. Crit Rev Clin Lab Sci 1989; 27: 27-58.

15 Urbanek R. IgG subclasses and subclass distribution in allergic disorders. Monogr Allergy 1988; 23: 33-40.

16 Van Loghem E. The immunoglobulin genes: genetics, biological and clinical significance. Clin Immunol Allergy 1984; 4:607-22.

17 Hvatum M, Scott H, Brandtzaeg P. Methodological pitfalls in determining IgG and IgG-subclass antibodies to food antigens. F Immunol Methods 1992; 148: 77-85.

18 Husby S, Foged N, Oxelius VA, Svehag SE. Serum subclass antibodies to gliadin and other dietary antigens in children with coeliac disease. Clin Exp Immunol 1986; 64: 526-35.

19 Kemeny DM, Urbanek R, Amlot PL, Ciclitira PJ, Richards $\mathrm{D}$, Lessof $\mathrm{MH}$. Sub-class of IgG in allergic disease. 1. IgG sub-class antibodies in immediate and non-immediate food allergy. Clin Allergy 1986; 16: 571-81.

20 Barnes RMR, Harvey MN, Blears J, Finn R, Johnson PM IgG subclass of human serum antibodies reactive with dietary proteins. Int Arch Allergy Appl Immunol 1986; 81: 141-7.

21 Rawcliffe PM, Jewell DP, Faux JA. Specific IgG subclass antibodies, IgE and IgG S-TS antibodies to wheat gluten fraction B in patients with coeliac disease. Clin Allergy 1985; 15: $155-62$.

22 Ciclitira PJ, Ellis HJ, Richards D, Kemeny DM. Gliadin IgG subclass antibodies in patients with coeliac disease. Int Arch Allergy Appl Immunol 1986; 80: 258-61.

23 Rognum TO, Kett K, Fausa O, Bengtsson U, Kilander A, Scott $\mathbf{H}$, et al. Raised number of jejunal IgG2-producing cells in untreated adult coeliac disease compared with food allergy. Gut 1989; 30: 1574-80.

24 Merrett J, Burr ML, Merrett TG. A community survey of IgG4 antibody levels. Clin Allergy 1983; 13: 397-407.

25 Bjerke K, Brandtzaeg P. Terminally differentiated human intestinal B cells. IgA and IgG subclass-producing immunocytes in the distal ileum, including Peyer's Patches, compared with lymph nodes and palatine tonsils. Scand 7 Immunol 1990; 32: 61-7.

26 Shakib F. Aspects of pathological significance of IgG4. Exp Clin Immunogenet 1987; 4: 193-200.

27 Aalberse RC Van der Gaag R, Leeuwen J. Serologic aspects of IgG4 antibodies. 1. prolonged immunization results in an IgG4 restricted response. $\mathcal{F}$ Immunol 1983; 130: 722-6.

28 Djurup R, Østerballe O. IgG subclass antibody response in grass pollen-allergic patients undergoing specific immunotherapy. Allergy 1984; 39: 433-41.

29 Hammarström L, Persson MAA, Smith CIE. Subclass distribution of human anti-Staphylococcus aureus alpha toxin antibodies: Suggestion of an IgGl, IgAl, IgG4 switch pattern. Scand $\mathcal{f}$ Immunol 1984; 20: 247-50.

30 Djurup R, Malling H-J, Søndergaard I, Weeke B. The IgE and IgG subclass antibody response in patients allergic to yellow jacket venom undergoing different regimens of immunotherapy. 7 Allergy Clin Immunol 1985; 76: 46-55.

31 Persson MAA, Ekwall E, Hammarström L, Lindberg AA, Edvard Smith CI. Immunoglobulin G (IgG) and IgA subclass pattern of human antibodies to Shigella flexneri and Salmonella serogroup B and D lipopolysaccharide O antigens. Infect Immun 1986; 52: 834-9.

32 Spigelberg HL. Biological activities of immunoglobulins of different classes and subclasses. Adv Immunol 1974; 19 259-93.

33 Unkeless JC, Fleith H, Mellmann JC. Structural aspects and heterogeneity of immunoglobulin $\mathrm{Fc}$-receptors. Adv Immunol 1981;31:247-70.

34 Garred P, Michaelsen TE, Aase A. The IgG subclass pattern of complement activation depends on epitope density and antibody and complement concentration. Scand F Immunol $1989 \cdot 30: 379-82$

35 Michaelsen TE, Garred P, Aase A. Human IgG subclass pattern of inducing complement-mediated cytolysis depends on antigen concentration and to a lesser extent on epitope patchiness, antibody affinity and complement concentration. Eur F Immunol 1991; 21: 11-6.

36 Isenman DE, Dorrington KJ, Painter RH. The structure and function of immunoglobulin domains. I Immunol 1975 114: 1726.

37 Van der Zee JS, Van Swieten P, Aalberse RC. Inhibition of complement activation by IgG4 antibodies. Clin Exp Immunol 1986; 64: 415-22.

38 Halpern GM, Scott JR. Non-IgE antibody mediated mechanisms in food allergy. Ann Allergv 1987; 58: 1+27.

39 Giessen Mvd Homann WL, Kernebeek Gv, Aalberse RC, Dieges PH. Subclass typing of IgG antibodies formed by grass pollen-allergic patients during immune therapy. Int Arch Allergy Appl Immunol 1975; 50: 625-40.

40 Reisman RE, Osur SL. Allergic reactions following first insect sting exposure. Ann Allergy 1987; 59: 429-32.

41 Nagata S, Glovsky MM. Activation of human serum complement with allergens. F Allergy Clin Immunol 1987; 80: 24-32.

42 Lavö B, Knutson L, Lööf L, Odlind B, Venge P, Hällgren R. Challenge with gliadin induces eosinophil and mast cell activation in the jejunum of patients with celiac disease. Am 7 Med 1989; 87: 655-60.

43 Kett K, Scott H, Fausa O, Brandtzaeg P. Secretory immunity in coeliac disease: cellular expression of IgA subclass and J chain. Gastroenterology 1990; 99: 386-92.

44 Halstensen TS, Hvatum M, Scott H, Fausa O. Brandtzaeg P. Immunopathology of celiac disease: association between subepithelial deposition of activated complement and immunoglobulin G response to gluten. Gastroenterology 1992 (in press). 